\title{
An Evaluation of Farmers' Participation in Afforestation Programme in Kogi State, Nigeria
}

\author{
O.J. Saliu \\ Department of Agricultural Economics and Extension \\ Kogi State University Anyigba, Nigeria \\ Tel: 234-807-721-0049Ｅ-mail: josaliu@yahoo.com
}

J.S Alao

Department of Forestry, Wild Life and Fisheries

Nasarawa State University, Keffi, Nigeria

T Oluwagbemi

Department of Animal Production

Kogi State University Anyigba, Nigeria

\begin{abstract}
Extensive deforestation has reduced the 65 million hectares of intact forest cover of 1897 in Nigeria to the present 4 million hectares. The consequences of this unhealthy development have resulted to environmental degradation and accelerated wind and water erosion of the fertile land that has also left Nigerian soil too poor for sustainable agricultural production. Reforestation through small-scale village based farmers' participation now form one of the strategies embarked upon by several agencies in Nigeria including Kogi afforestation project. This study attempts to evaluate farmers' participation in afforestation project in Kogi State. Structured questionnaire was used to interview 120 participants. Descriptive statistics, adoption index and sigma method were used to describe socio-economic characteristics, participation methods and to measure the level of adoption while chi-square was used to find differences between income generated from adoption of the various afforestation technologies. Findings reveal that 67 percent of the farmers had little or no formal education, more than 30 percent of the farmers underwent passive participation in afforestation while adoption of improved seedlings, exotic trees and pure stand technologies received high score of 4.90, 4.74 and 4.44 respectively. Seed scarification and harvesting by chipping technologies received the least adoption score of 2.61 and 2.94. The chi-square test adjudged that there was a significant difference between income generated and type of technology adopted. This study recommends that more pragmatic interactive participation method that will give room for joint analysis of action plan and formation of local institutions should be put in place.
\end{abstract}

Keywords: Participation, Afforestation-Technology, Deforestation and reforestation

\section{Introduction}

Nigeria had about 65 million hectares of intact forest cover in 1897 but presently the forest cover has reduced to four million hectares (Ikojo, 2008). Population explosion, indiscriminate felling of trees for timber, over exploitation of firewood for fuel and charcoal, clearing of land for agricultural expansion and industrial development have exposed the land to rapid soil organic matter decomposition, accelerated water and wind erosion, flooding, land slide, desertification and threat of extinction of economic trees (Adedire, 2007). These hazards result in environmental degradation and make sustainable agriculture increasingly difficult.

Many countries have taken steps to arrest the rate of deforestation through programmes such as afforestation, domestication of medicinal plants and protection of threatened species. Attempts to create awareness about tree planting started around the late thirties especially in the northern parts of Nigeria (Adegbehin et al; 1998).

Today, tree planting is being recognized as a sector which is a key to any afforestation strategy of long-term development. In 1985, a consortium of international agencies including the World Bank and World Resources Institute, unveiled a far-reaching strategy to halt the destruction of forests in the third world. The report stressed 
that the destruction of forest was having a profound impact on the third world food production and as such recommended that policies should be established to encourage local participation in rural afforestation programme and natural forest management (Bertus et al; 1991).

The implication is that government reforms designed to reduce wide-spread deforestation have to be complemented not only by larger scale reforestation programmes but by small - scale village based tree growing exercise. This practice was based on the understanding that managing forests with communities through farmers participation, will strengthen forest law enforcement.

Farmers' participation in afforestation is gaining recognition owing to the fact that successful management of forest resources rest on the support, understanding and cooperation of the farmers as individual farmer's bring their respective knowledge and practice to bear. Failure to integrate local knowledge and practice in new technologies has led to unsuccessful research results (Schulz et al; 2001). The knowledge of indigenous practice could therefore present useful information on a wide range of production activities.

Ananda (2004) reported that, the success of participation can be evaluated against several 'social goals' such as incorporating public values into decision making and resolving conflict among competing interests. He maintained that, planning process also influences public participation. Commitment by governments and agencies to a participatory approach is essential in winning the trust of the stakeholders before any meaningful participation can be guaranteed. Current developments in environmental policy recognize the importance of public participation in planning and policy making endeavours.

Enthusiasm is the driving force that can move a programme away from paternism to increasing participation. This may occur in both decision-making and programme execution. Participation can provide tremendous advantages for development programme. Involvement of local people helps to ensure that the programme will respect local cultural values and will be continually oriented towards the people's felt need. Participation is the cooperation of farmers in the execution of the extension programmes by attending extension meetings, demonstrating new methods on their farms and listening to different farmers in order to understand their needs, goals and opportunities through consultation (Vandan ban and Hawkins, 1996). For a successful participation, it is desirable that ordinary farmers gain insight into decision made for the extension programmes. Effective participation begins with participatory efforts being developed as a process to fit the rhythms of local communities and within a time frame long enough to ensure continuity.

Bigs (1989) cited by Bertus et al. (1991) distinguishes four types of farmers participation as contractual, consultative, collaborative and collegiate while Pretty (1994) asserted that participation can be differentiated into seven types. He argued that participation could be passive, information giving, consultative, material incentives, functional, interactive and self-mobilization. Participation is said to be passive when participants are merely told the plan that was decided a priori by the administrator without any input or contributions from the clienteles. An information giving type of participation is so called when clienteles are being made to respond to a set of questionnaire with little influence on the proceedings by the target group. Participation by consultation gives room for people to be consulted while external agents listen to opinions or views of the clienteles.

Participation by material incentives is a method where farmers provide resources such as field but not involved directly in the process of learning. Functional participation is a style that involves target group not at the planning stage but after major decisions have been made. Interactive participation allows a joint analysis, which leads to action plans and the formation of new local institutions or the strengthening of the existing ones, through the use of structured learning process. Self-mobilization is a method whereby people participate by taking initiative independent of external institution. However the participants may seek for external assistance in terms of fund mobilization and provision of technical know how. An afforestation practice that has been embraced through self-mobilization by the clienteles may likely be a sustainable one especially if it receives political support from the government, social and natural support from its immediate environment.

In order to accelerate sustainable afforestation exercise particularly in the States bordering the semi-arid region of Nigeria, the Federal Government of Nigeria setup the now defunct National Committee on Arid Zone Afforestation (NCAZA) in 1979. The publicity exercise was further intensified when the yearly tree planting campaign was launched by the Federal Government in all the States of the federation. This campaign has since become an annual event in Nigeria.

Kogi State government embraced the tree planting campaign which received financial support from the World Bank between 1978 and 1984. An afforestation Project otherwise called Kogi Afforestation Project was then put in place. The project established government afforestation plots, prepared nurseries for improved tree seedlings and sold to farmers. The project also diffused and educated farmers on tree planting. Farmers were expected to 
use afforestation technologies disseminated to them. Having rested the project for some years, it has become pertinent to ask the following questions: What are the socio-economic characteristics of the farmers? Did the farmers adopt the species of trees introduced to them? What type of participatory method used for the adoption of the afforestation technologies? Was it contractual? consultative? collaborative or collegiate according to Bertus et al. (1991) or was it passive? information giving? material incentive? functional participation? interactive and or self-mobilization as explained by Pretty (1994)?

The objectives of this study are therefore to:

(a) Describe the socio-economic characteristics of the farmers

(b) Identify the various types of participatory methods used by the afforestation agency.

(c) Assess the level of adoption of tree-planting technologies by the farmers in the study area

(d) Find out if there is any difference in income generated from different afforestation technologies adopted.

\section{The Study Area}

Kogi State otherwise known as the "Confluence State" because of the location of its capital Lokoja at the point where rivers Niger and Benue meet, is one of the nine States created on the $27^{\text {th }}$ of August 1991 through excision of parts of former Benue and Kwara States. This State is in the north central zone of Nigeria located between latitude $6^{0} 30 \mathrm{~N}$ and longitude $5^{0} 51 \mathrm{E}$ and $8.00 \mathrm{E}$ with a maximum temperature of $53.2^{\circ} \mathrm{C}$ and average temperature of $22.8^{0} \mathrm{C}$ (KOSEEDS, 2004). Kogi State has an average relative humidity of 70 percent. Rain usually starts in March and records double maxima in June and September of every year with average daily hours of sunshine at 6.2 hours.

The State has about 2 million hectares of cultivable land but only about 0.5 million hectares are under cultivation. About $73.5 \%$ of the cultivable land $(1,470,000 \mathrm{ha})$ can be cultivated in the raining season while $26.5 \%$ $(530,000 \mathrm{ha})$ is suitable for dry season farming (KOSEEDS, 2004).

The confluence of rivers Niger and Benue provides alluvial fertile soil suitable for the production of a good number of crops. Notable crops grown in the State are; maize, rice, guinea corn, yam, cowpea, citrus, oil palm, cocoa, coffee and kola nut. Cattle, sheep, goat, poultry and fish are also found in significant number. Afforestation projects were established in two zones of the State in 1978. One was situated in the eastern flank of the State and the other in the western part. Kogi State shares common boundaries with Niger, Plateau and Nassarawa States and the Federal Capital Territory Abuja to the North, to the east, is bordered by Benue State. To the west it is bounded by Kwara, Ekiti and Ondo States and to the south by Enugu and Edo States. The State has an area of 28,312.64 square kilometers and a population of 3,278,487 out of which 1,691,737 are males and $1,586,750$ are females according to 2006 population census. The State has average of 172,000 farm families where about $70 \%$ of the population live in the rural areas and engage in agricultural production (FGN, 2007). The State is made up of 21 local government areas.

\section{Sampling Techniques}

The study was carried out in the six sub stations where government established afforestation plots in Dekina, Idah and Igalamela Odolu Local Government Areas. The total population of afforestation farmers in the study area was estimated to be one thousand, one hundred and ten $(1,110)$ which spread across the six villages where the afforestation programems are located. The villages are; Acharu, Ogbogodo, Ochi-Ofago, Okura, Oforachi and Alade.

Twenty (20) respondents were randomly selected from each of the six villages to make a total sum of 120 respondents. Structured questionnaire was designed to quest for data on the afforestation practices engaged in by farmers, socio - economic characteristics, afforestation technology adopted by farmers and participatory methods used to involve the clienteles. Some copies of the questionnaire were tested and rested within two weeks interval among the same respondents for reliability using Pearson moment correlation coefficient. The questionnaire was found to be reliable at $r=0.72$ that is about 72 percent reliable. Ambiguous words were removed to improve on the reliability of the questionnaire. The copies of the questionnaire were administered to the respondents using trained data collectors. One hundred and ten questionnaire were finally retrieved for data analysis.

\section{Data Analysis}

Descriptive statistics such as frequency and percentages were used to describe the socio-economic characteristics of the farmers and the type of participatory methods used by the afforestation project while adoption levels of the 
various afforestation technologies adopted were measured by obtaining adoption scores through sigma method. That is standardizing frequency and percentages by mathematical procedures to obtain normalized standard scores as described by Agbamu (2006). In this model percentage of farmers who adopted an innovation is obtained and a value known as sigma distance which is read from the statistical table of normal deviate is secured. The model is computed as follows;

$100-\frac{\text { pecentagewhoadopted aninnovation }}{2}$ to give a figure that can be interpreted as sigma distance when read from normal deviate statistical table by checking the first two digits in vertical row and the fraction under column. A constant 2 is added to the sigma distance and multiplied by this same constant. That is (Sigma distance +2$) 2$.

Sigma method of scoring, assigns weights in reverse relation on a 10 point scale. As such adoption score $=$ 10-(sigma distance+2)2.

Chi-square was also used to find differences between income generated among different technologies adopted using model:

$$
\frac{\Sigma(f o-f e)^{2}}{f e}
$$

Where fo $=$ observed frequency

$\mathrm{fe}=$ expected frequency

$\sum=$ summation sign

\section{Results and Discussion}

Table 1: shows that about 77.3 percent of the respondents were married while only 5.50 percent were single. This implies that any afforestation technology that will need the cooperation of husband and wife to take decision on its adoption may receive a lot of clienteles that could participate in such activities since majority of the clienteles were married.

About 67.3 percent of the respondents had little (37.3 percent) or no formal education (30.0 percent) while only 14.5 percent had University degrees. As such this implies that instructions written in English might be difficult to interpret by 67.3 percent of the respondents and afforestation technology that requires complex steps or technical processes may not be readily adopted due to the low literacy level that may affect as high as 67.3 percent of the respondents.

About 65.46 percent of the respondents were within the ages of $31-40$ years while only 8.18 percent of the respondents were above fifty years of age. This signifies that a very high percentage of the respondents fell under active economic productive age and as such may still pick interest on whatever can boost their economy. Such age group may therefore be willing to participate in afforestation programme that will improve the level of their income.

About 81.82 percent had between 1 - 5 (35.46) percent and $6-10$ (46.36) percent family sizes while only 1.82 percent had 16 and above family size. This points to the fact that a very high proportion of the respondents can utilize family labour to execute farm work. An afforestation technology that requires labour may not suffer any setback if the members of the family are willing to put in their labour for such afforestation exercise.

The afforestation farm size as per number of trees planted reveals that about 54.54 percent of the respondents planted less than 200 trees while only 23.64 percent had between 301 and 400 trees on their farms. This implies that a very high proportion of the farmers planted very few number of trees. There is therefore more room for improvement on tree planting exercise. A well planned people centered strategy on afforestation may lead to such improvement.

As seen in Table 2, only three participatory methods out of the seven received responses from the respondents. The three are; passive, consultative and material incentives. Regarding seedling technology introduced to the farmers 53.64 percent of the respondents participated in improved seedlings while only 12.73 percent participated in scarification technology. However, 41.82 percent of the respondents participated by consultation while 33.63 participated passively. 
This implies that a significant number of the respondents who participated in the seedling technology were not consulted to express their felt need and value for seedling and technology of their choice. This may reduce the expected inspiration and possibly the adoption of the said technology (Scoones and Thompson, 1994).

Under non-woody harvesting technology, 46.36 percent passively participated while only 20.91 percent of the respondents participated by consultation. However, under processing/marketing technology, 41.82 percent of the respondents participated by consultation while 36.36 participated passively. Respondents who participated by consultation under tree harvesting technology was 49.09 percent while 20.00 percent participated through material incentives and 30.91 participated passively. This implies that participation by consultation is gaining recognition in the adoption of afforestation technology. From the table 2, it is logical to say that the type of participation depends on the type of afforestation technology involved as it was observed that participation by consultation had the least percentage under non-woody harvesting technology. Be that as it may, it is pertinent to state that if afforestation is to be self-sustaining one looks forward to observe a practice in which interactive and self mobilization types of participation would receive attention from afforestation implementing agencies and as such used to enhance level of participation in afforestation (Pretty, 1994).

As observed in Table 3, afforestation technologies such as exotic trees, improved seedlings, timber exploration, fruit collection, pure stand species and indigenous trees received high adoption scores of 4.90, 4.79, 4.73, 4.47, 4.44 and 4.38 respectively while technology such as clipping, seed scarification and pulping had low adoption scores of 2.61, 2.94 and 3.22 respectively. Selective exploration was adopted on a little above average level. This implies that farmers in the study area would welcome afforestation technologies with high adoption scores. However effort must be made to persuade the farmers to accept selective exploration, adoption of mixed stand, the use of clipping and scarification to reposition the state of afforestation in the area. This is likely to bring back the natural woody guinea savanna belt of the area which has now turned to grassland.

Calculated $x^{2}$ value is 23.31 which is greater than the tabulated value of 9.49 at 0.05 significant level, at 4 degree of freedom and so there is a significant difference between technology adopted and income generated from such technology. In essence, income generated from the afforestation technologies adopted was not the same. Possibility exists that farmers may concentrate more on technologies that would fetch them more money. It is however necessary to adopt all the technologies put across to farmers especially to bring back the threatened species.

\section{Conclusion}

Farmers' participation in afforestation is expected to stimulate and sustain adoption of tree planting technologies. A very high percentage of farmers are still passively involved in afforestation exercise, this may not lead to effective participation and farmers may refuse to adopt or discontinue the adoption of afforestation technology. More pragmatic and dynamic participation methods such as interactive and self-mobilization should be initiated and adopted by the afforestation implementation agencies if environmental degradation and desertification must give way for sustained green cover of Kogi State, in particular and Nigeria in general.

\section{Recommendation}

1. The participatory methods must be overhauled for pragmatic interactive methods, which will give room for joint analysis of action plan and formation of local institution.

2. Community nurseries should be enlarged to ensure availability of the seedlings of farmers' choice as there was a high adoption score for improved seedlings. The species of seedling adopted should be identified and multiplied in folds for farmers use. Self-mobilization participation in community nurseries should be encouraged for affordable or sustainable seedling propagation.

3. Adult education should be encouraged to reduce level of illiteracy and enhance participation and adoption of afforestation technology.

4. Non-governmental organizations and private sector should be committed in assisting farmers especially any group of farmers who may want to initiate self-mobilization type of participation. They should make their rules flexible enough to accommodate active rural farmers participation.

5. The Federal, State and Local Governments must be ready to improve on the methods of involving farmers in the problems that affect them especially as it was observed that the afforestation agencies still used passive participation method to involve a significant number of farmers. 
6. Researchers should carry out more investigations in order to improve on the economic values of indigenous trees since many of the farmers still plant them as revealed in the study. This must be done through the active participation of the farmers and based on their indigenous knowledge practices.

\section{References}

Adedire, M.O. (2007). Tropical Deforestation; A. Threat to Sustainable Forest and Wildlife Management Convocation Lecture delivered to mark the $41^{\text {st }}$ and $43^{\text {rd }}$ Join Convocation Ceremony of Federal College of Wildlife Management New Bussa at the Federal College of Forestry, Ibadan. 2.p.

Adegbehin, J.O. Gbadegesin, R.A, Dauda, C.K., Uyobi Sere, E. Nasiru, M. Aribido, S.O. and Akpoko, J.G. (1998). A survey of Farmers Response to tree planting campaigns in Kaduna State. The Nigerian Journal of Agricultural Extension, 11 (1 \& 2) 135.p.

Agbamu, J.U. (2006). "Essentials of Agricultural Communication in Nigeria”. Malthouse Press Limited Publishers $80-83$.

Ananda, J. (2004). Implementing Participatory Approaches in Formulating Regional Forest Policy International Journal of Sustainable Development, p. $399-404$.

Bertus, H., Johan U.K. and Waters - Bayers A. (1991). Joining Farmers Experiments. Intermediate Technology Publications 6 -29.p.

Federal Republic of Nigeria. (FGN, 2007). Federal Republic of Nigeria Official Gazette Vol. 94 No. 24. 182.

Ikojo, H.A. (2008). Deforestation and Its Consequences for the Nigerian Environment. In: Ezike, K.N.N, Osakwe, I.I, Ekwu I.G., Utobo, E and C.N. Mbah (eds). Agricultural Development in Nigeria: Issues and Challenges. Proceedings of the $42^{\text {nd }}$ Annual Conference of the Agricultural Society of Nigeria (ASN) held at Faculty of Law Auditorium, CAS Campus, Ebonyi State University, Abakaliki, Nigeria October 19 - 23. 387 389.p.

KOSEEDS, Kogi State Economic Empowerment and Development Strategy. (2004). Towards Poverty Alleviation and Wealth Creation. Printed by Kogi State Ministry of Budget and Planning 3-6.

Pretty, J.N. (1994). Participatory Types, Adapted from Adnan, S. Barette A, Nurul-Alam, S.M. and Brustinow A. (1992). Peoples' Participation: NGO's and the Flood Action Plan. Dhaka, Bangladesh: Research and Advisory Services $61-68$.

Schulz, S. Carsky, R.J. and Tarawali S.A. (2001). Herbaceous Legumes. The panacea for West Africa soil fertility problems, sustaining soil fertility in West Africa. Soil Science of America and American Society of Agric, 28: $179-190$.

Scoones, I and Thompson. (1994). Trees, People and Communities in Zimbabwe's communal lands. Beyond farmer first. Intermediate technology publications $71-72$.

Van den Bau A.W. and Hawkin H.S. (1996). Agricultural Extension - Second Edition. Blackwell Science Limited, p. $219-220$. 
Table 1. Socio-Economic Characteristics of Respondents

\begin{tabular}{|c|c|c|c|}
\hline $\mathbf{S} / \mathbf{N}$ & CHARACTERISTICS & FREQUENCY & PERCENT \\
\hline \multirow[t]{6}{*}{1} & Marital Status & & \\
\hline & Single & 6 & 5.46 \\
\hline & Married & 85 & 77.27 \\
\hline & Widowed & 11 & 10.00 \\
\hline & Divorced & 8 & 7.27 \\
\hline & Total & 110 & 100.00 \\
\hline \multirow[t]{6}{*}{2} & Educational Attainment & & \\
\hline & Non Formal Education & 18 & 30.00 \\
\hline & Primary School & 72 & 37.27 \\
\hline & Secondary School & 11 & 18.18 \\
\hline & Degree & 9 & 14.55 \\
\hline & Total & 110 & 100.00 \\
\hline \multirow[t]{6}{*}{3} & Age Distribution & & \\
\hline & $20-30$ & 18 & 16.36 \\
\hline & $31-40$ & 72 & 65.46 \\
\hline & $41-50$ & 11 & 10.00 \\
\hline & 50 and above & 9 & 8.18 \\
\hline & Total & 110 & 100.00 \\
\hline \multirow[t]{6}{*}{4} & Family Size & & \\
\hline & $1-5$ & 39 & 35.46 \\
\hline & $6-10$ & 51 & 46.36 \\
\hline & $11-15$ & 18 & 16.36 \\
\hline & 16 and above & 02 & 1.82 \\
\hline & Total & 110 & 100.00 \\
\hline \multirow[t]{6}{*}{5} & Farm Size & & \\
\hline & $1-100$ & 33 & 30.00 \\
\hline & $101-200$ & 38 & 34.54 \\
\hline & $201-300$ & 13 & 11.82 \\
\hline & $301-400$ & 26 & 23.64 \\
\hline & Total & 110.00 & 100 \\
\hline
\end{tabular}

Source: Field Survey 2007 
Table 2. Participatory Methods Used For Implementing Different Categories of Afforestation Technologies

\begin{tabular}{|c|c|c|c|c|c|c|}
\hline $\mathbf{S} / \mathbf{N}$ & $\begin{array}{ll}\text { Categories } & \text { of } \\
\text { technology } & \\
\end{array}$ & Frequency & Percentage & $\begin{array}{l}\text { Passive } \\
\text { Participation }\end{array}$ & Consultative & $\begin{array}{l}\text { Mal } \\
\text { incentives }\end{array}$ \\
\hline \multirow[t]{7}{*}{1} & Seedling technology & & & & & \\
\hline & Improved seedlings & & & & & \\
\hline & Scarification & & & & & \\
\hline & Direct seedling & 59 & 53.64 & 20 & 21 & 18 \\
\hline & & 14 & 12.73 & 4 & 8 & 2 \\
\hline & & 37 & 33.63 & 13 & 17 & 7 \\
\hline & Total & 110 & 100.00 & 37 & 46 & 27 \\
\hline \multirow[t]{8}{*}{2} & Tree harvesting & & & & & \\
\hline & technology & & & & & \\
\hline & Selective extraction & & & & & \\
\hline & Total felling & 28 & 25.45 & 9 & 14 & 5 \\
\hline & Clipping & 37 & 33.64 & 11 & 21 & 5 \\
\hline & Frame collection & 10 & 39.09 & 3 & 5 & 2 \\
\hline & & 35 & 31.82 & 11 & 14 & 10 \\
\hline & Total & 110 & 100.00 & 34 & 54 & 22 \\
\hline \multirow[t]{8}{*}{3} & Non-woody harvesting & & & & & \\
\hline & technology & & & & & \\
\hline & Leaves collection & & & & & \\
\hline & Fruit collection & & & & & \\
\hline & Root and bark & 38 & 34.55 & 18 & 8 & 12 \\
\hline & & 49 & 44.54 & 23 & 10 & 16 \\
\hline & & 23 & 20.91 & 10 & 5 & 8 \\
\hline & Total & 110 & 100.00 & 51 & 62 & 36 \\
\hline \multirow[t]{7}{*}{4} & Processing/ & & & & & \\
\hline & marketing technology & & & & & \\
\hline & Saw milling & & & & & \\
\hline & Pulping & 52 & 47.27 & 18 & 22 & 12 \\
\hline & Electric poles & 13 & 11.82 & 6 & 3 & 4 \\
\hline & & 45 & 40.91 & 16 & 21 & 8 \\
\hline & Total & 110 & 100.00 & 40 & 46 & 24 \\
\hline
\end{tabular}

Source: Field Survey 2007 
Table 3. Adoption Scores for Afforestation Technology Adopted N $=110$

\begin{tabular}{|lllll|}
\hline S/N & Technology adopted & $\begin{array}{l}\text { Frequency } \\
\mathbf{n = 1 1 0}\end{array}$ & Percentage & $\begin{array}{l}\text { Adoption } \\
\text { score }\end{array}$ \\
\hline 1 & Improved seedling & 59 & 53.6 & 4.74 \\
& Direct seeding & 37 & 33.6 & 4.08 \\
& Seeds Scarification & 14 & 25.5 & 2.94 \\
Selective extraction & 28 & 33.6 & 3.72 \\
Total felling & 37 & 9.09 & 4.08 \\
Clipping & 10 & 31.8 & 2.61 \\
Prune collection & 35 & 34.5 & 4.00 \\
Leaves collection & 38 & 44.5 & 4.12 \\
Fruit collection & 49 & 20.9 & 4.47 \\
Root and bark & 23 & 45.5 & 3.48 \\
Saw milling & 50 & 16.4 & 4.50 \\
Pulping & 28 & 40.1 & 3.22 \\
Electric poles & 45 & 41.8 & 4.35 \\
Indigenous trees & 46 & 58.2 & 4.38 \\
Exotic trees & 64 & 43.6 & 4.90 \\
Pure stand species & 48 & 31.8 & 4.44 \\
Mixed stand species & 35 & 24.5 & 4.00 \\
Regeneration & 27 & 41.8 & 3.67 \\
Agro forestry & 46 & 30.9 & 4.38 \\
Fruit tree seedlings & 34 & 52.7 & 3.96 \\
Timber & 58 & & 4.73 \\
\hline
\end{tabular}

Source: Field Survey 2007

Table 4. Data Generated For Chi-Square

\begin{tabular}{|llllll|}
\hline S/N & Technology adopted & \multicolumn{2}{c|}{ Category of income generated from technology } & $\begin{array}{c}\text { Total } \\
\text { adopted in Naira }\end{array}$ & frequency \\
\hline 1 & Technology adopted & $1-10,000$ & $11-20,000$ & $21-30,000$ & \\
& Fruit trees & 13 & 16 & 5 & 34 \\
& Timber & 10 & 18 & 30 & 58 \\
& Multipurpose & 11 & 5 & 2 & 18 \\
\hline & & 34 & 39 & 37 & 110 \\
\hline
\end{tabular}

Degree of freedom $=\mathrm{R}-1(3-1) \times(\mathrm{C}-1)(3-1)=2 \times 2=4$

Source: Field Survey 2007 
Table 5. Chi-Square Calculation

\begin{tabular}{|lllll|}
\hline fo & fe & fo-fe & $(\text { fo-fe })^{2}$ & $\frac{(f o-f e)^{2}}{f e}$ \\
\hline 13 & 10.51 & & & 0.5899 \\
10 & 17.93 & 2.49 & 6.2001 & 3.5072 \\
11 & 5.56 & -7.93 & 62.884 & 5.3226 \\
16 & 12.05 & 5.44 & 29.5936 & 1.2948 \\
18 & 20.56 & 3.95 & 15.6025 & 0.3187 \\
5 & 6.38 & -2.56 & 6.5536 & 0.2985 \\
5 & 11.44 & -1.38 & 1.9044 & 3.6253 \\
30 & 19.51 & -6.44 & 41.4736 & 5.6401 \\
2 & 6.05 & 10.49 & 110.0401 & 2.7111 \\
& & -4.05 & 16.4025 & \\
\hline & & & 23.31 \\
& & & & \\
\hline
\end{tabular}

Source: Field Survey 2007 